\title{
To Understand the Team Cohesiveness, Teamwork Quality and Team Performance in Employee Performance in University
}

\author{
Zairina Ibrahim, Normy Rafida Abdul Rahman, Md Gapar Md Johar
}

\begin{abstract}
The purpose of this research is to seek and identify the impact teamwork has on organizational performance. The research to understand the team work quality, team cohesiveness and team performance in employee performance, identify the positive or negative effects of teamwork on employees and to examine the impact of teamwork on organization performance. Therefore, it is to determine how teamwork could effect and improve University employee's performance within the organization. In fact, it is also to understand on how methods like teamwork quality, team cohesiveness, and teamwork performance have could be used to have positive effects in employee overall performance. The research study used correlation techniques in order to analyze the relationship between two variables that was Teamwork and Organization Performance. In many of the journals and article that was collected, there was clear evidence that teamwork and other measures of team performance are positively related with organization performance. The study of the research shown that there was a significant positive impact of teamwork on organizational performance and employee's overall performance.
\end{abstract}

Index Terms: Team Cohesiveness, Teamwork Quality, Team Performance, Employee Performance.

\section{INTRODUCTION}

In globalization era today, there are have been so much emphasis on pride and personal achievement at workplace, where by the concept of teamwork seems to be overlooked by managers and employees. Thus, this research is to analyze the understanding of few characteristic which are team cohesiveness, teamwork quality and team performance in employee performance amongst the Staffs in University. The University is a huge company, therefore, a University has a large amount of employees this including the academician and the non-academician. The idea to do a conduct about teamwork in University is because teamwork play an important role to improve the relations among the

Revised Manuscript Received on September 22, 2019.

Zairina Ibrahim, Information Technology and Innovation Centre, Managem and Science University, University Drive Seksyen 13, Shah Alam 40100, Malaysia.

Normy Rafida Abdul Rahman, Faculty Business Management and Profess Studies, Management and Science University, University Drive Seksyen 13, Shah 40100, Malaysia.

Md Gapar Md Johar, Information Technology and Innovation Centre Management and Science University, University Drive Seksyen 13, Shah Alam 40100, Malaysia. employees, the bigger of teamwork that applied in each activities in the company then it would be increase University performance.

Therefore, the years of 5 years which as 2013 until 2018, the University has achieved so many awards and recognitions locally and globally. In fact, this shown that with efficient practice of teamwork, will lead to a positive impact towards the company.

However, part of a team's performance depends on the knowledge, skills and abilities for its members. A team's performance is not merely summation of its individual member's abilities. Besides that, these abilities set parameters for what members can do and how effectively the employee will perform on a team.

Nevertheless, within the context of team cohesiveness, teamwork quality, team performance and employee performance in University, we intend to explore the understanding of the following criteria amongst the University employees.

\section{A. Problem Statement}

In the recent years 2018, organization have facing many changes towards their teamwork among the employees. The aim of this research is to determine the level of satisfaction in their teamwork services in term of employment skills. This research also will be examined the relationship among the Students at the Universities between the academician and non-academician members at their department. There are many Students have been affected by the Universities academician services. The Universities should be alert with this condition that involved the academician and non-academician as well because the Universities will have an increasing number of Students. In fact, it can lead the higher demand toward the teamwork among them self.

According to [17], there is no research taken in Malaysian Universities on the teamwork among the academician and non-academician. Thus, teamwork in Malaysia are not free from customer satisfaction issue. In order to meet customer demand and satisfaction, the entire team collaboration including employment skills must be achieved as well. Furthermore, the elementary factors that contribute to the academician and non-academician satisfaction in their own department are including the employment skills that is onal teamwork, integration and trust [20]. 
In addition to team performance as an important team outcome, top management approval also represents a key result for teams. However, top management approval denotes the quality of the social relationship between an entire team and its top management, in which the top management provides recognition/approval to the team by endorsing for and agreeing with the team [35]. Therefore, the top management in this research is a person who directs and controls an entire division or department such as which often consists of many work teams at the same time at the highest level [20].

\section{B. Objective}

The University has a huge amount of Students and Staff. An employee performance may affected by numerous factors at workplace and will impact the organization either in a positive or negative way. In order to keep the rating high and maintain the good performance of University, an important role to achieving the goals for university. The purpose of this research objective is to understand the teamwork quality, team cohesiveness and team performance in employee performance. Specifically, however, the research examines:

a) To determine the relationship between team cohesiveness and employee performance

b) To determine the relationship between teamwork quality and employee performance.

c) To determine the relationship between team performance and employee performance

\section{LITERATURE REVIEW}

The teams are pervasive in today's world, and rightfully. A team is a formal group of members who interact at a high level and work together intensely to achieve a common group goal [5]. Thus, the impact of teams on organizational performance has been a topic of many researches done by academics and practitioners for the previous years. In fact, it is common to hear of management teams, production teams, service team or even whole organizations being referred to as teams. Besides that, many organization today are moving towards team based approach to work, this means that working in teams is the basic method used to get work done in these organizations. This research is conducted to understand the teamwork cohesiveness, teamwork quality and team performance in employee performance amongst the Staff in University.

\section{A. Teamwork Quality}

Teamwork can be defined and deliberated by some researchers as an essential occupational skill that is necessary to accomplish and achieve the visions, goal, plans and objectives of the organization and to active and enhance the performance of the workers there [27]. In fact, that teams need to communicate and share documents. Thus, success of team, voluntary or delegated is greatly influenced by the technical support like recognition and reward, education, encouragement, training, facilitation, skills that available to employees [7].

The recognition of team efforts and management encouragement are important in attracting employees to participate in teamwork. The most common reasons for failure of employees to participate in teamwork are lack of time and the negative influence of company politics. Nevertheless, a team as a whole can possess most of the desirable characteristics. According to [4], an eminent researcher and acknowledge expert of teams, the most successful team have a distribution of the eight specific team roles of coordinator, shaper, plant, monitor, evaluate, company worker, resources investigators, team worker and specialist [21]. A team should be composed by a group of people who are receptive to change, thus encouraging and contributing to innovation.

The teams that include creative personalities and functional diversity have an impact on the creativity of the team and encourage the implementation of processes innovation. Teamwork has been associated with high level of staff satisfaction and improved quality of care. In the project management field, utilized Effective Teamwork Assessment Matrix created by a company named constructing excellence. It is widely used by the business field to assess corporate teamwork quality. It consists of variables such as team identity, shared vision, communication, collaboration and participation, issue negotiation and resolution and reflection and self-assessment. However, studied the relationship between teamwork and product quality. They views factors of teamwork as helpfulness, coordination of efforts, open communication and friendliness [3].

\section{B. Team Cohesiveness}

The means of cohesion is an action or fact of forming a united whole. The concept of cohesion has been empirically linked with a number of group and individual variables. Therefore, [23] group variables include a positive relationship with team performance, collective efficacy and group norms. Stated by [33], team cohesion reflects the degree to which members are committed to one another in the achievement of team goals. Factors that are purported to contribute to team cohesion include number of team session, amount of time in the team, team size, team accountability and rewards for success.

Team cohesion is a factor that is related to academic performance outcomes in team-based learning (TBL). In fact, to suggest that member of low cohesion team are less likely to pull together in high-pressure situation and perform poorly as a team. It has long been purported that TBL activities should promote team cohesiveness because more cohesive teams are associated with better performance outcomes. Besides that, team cohesiveness describes the process where group members attach themselves to each other in order to achieve intended objectives and/or due to emotional interaction between them and sustain this state. In fact, it is stated that the pleasure felt due to the long-time togetherness of team members, homogeneity of group, size of group, cooperation in group and successful performance is an important factor to constitute and develop cohesiveness in a sportive group.

There are many factors influencing team cohesiveness, one of the strongest sources of group cohesiveness is the similarity in attitude and values among group members. Team 
cohesiveness are critical for success in today's org [11], regardless of whether teams operate in an office setting [31]. Based on [26], the nature of cohesiveness in a group is a reflection of the level of communication and bonding among group members and results in task, role commitment, group pride and interpersonal attraction. Overall, a good cohesiveness teams also provided a source of backup and assistance for overworked or under-skilled team members and can be a source of positive affect and increase morals [28].

\section{Team Performance}

According to [19], Teams have a powerful impact on the performance of the employees and the future of the organization. The studies that have been conducted on the subject indicate that the concept of teams is valuable and helpful to facilitate the development process in the organization and to enhance employee's performance.

According to [2] identified the two essential factors that promote the communication skills between team's members and enhance their performance regarding the concept of teamwork, which are: self-management team and interpersonal team skills. However, a performance is a systematic general and periodic process that assess an individual employee's job performance and productivity in relation to certain pre-established criteria and organizational objectives. In fact, many employees serve on teams, but their performance on the team may or may not even come up specifically in their performance appraisal. It is mean the performance is not only appearing from team, but the individual itself have a performance.

According to [21] recognition and rewards are the primary focus if the individuals who are working in teams. Team performance is defined as the extent to which a team accomplishes its goals or mission. Therefore, it's because team members interact interdependently in order to be successful, team members must engage in a number of team processes or interdependent acts that convert inputs to outcomes through cognitive, verbal, and behavioral activities directed toward organizing task work to achieve collective goals [14].

Therefore, the successful performance for any team requires members who can complete the technical portions of the team goals or mission for example to have specialized expertise, as well as effectively navigate team processes. In general, team composition is thought to be related to team performance because it affects the amount of knowledge and skill team members have to apply to the team task which as in terms of both task completion and working inter-dependently.

Additionally, member personality traits may also affect team performance by creating contextual influences on member behaviors. However, the effects of individual differences on team performance are complicated by the general multilevel nature of teams, it neglects the possibility that the team-level personality composition exerts top-down effects on team member behaviors [16]. In other words, organizational development activities increased self-efficacy and this increase helped explain the improved performance [1].

\section{Employee Performance}

A performance management system fir identifying, differentiating and rewarding performance of an employee, comprising means for communicating performance status to the employee for communicating to the employee differences between the communicated performance status and performance standard associated with the employee and for developing a prescriptive path for the employee. An employee performance can be defined as team effectiveness, teamwork quality and employee satisfaction. Furthermore, it also can explicitly as the degree to which a go groups output meet requirements in terms of quantity, quality and timeliness performance, the group experience improves its members ability to work as a group in the future behaviour and the group experience contributes to individual satisfaction [10].

Performance is an outcome achieved by workers in their work according to certain criteria applied for a particular job. An employee performance refer to one's achievement measured by the standards of criteria set by the company. Furthermore, overall outcome or level of success of a person during certain periods in performing the tasks compared with the standards of the work, goals or targets or criteria that have been determined in advanced and have been agreed upon [25]. In fact, stated that performance does not stand alone, but it is related to job satisfaction rewards, influenced by skills, abilities and individual traits. Therefore, to have a good performance, one must have a high desire to do and know his/her work and it can be increased if there is a conformity between job and ability [30].

Since teamwork is performed by individuals, it is also important to measure team performance at the individual level. Thus, it's can achieve a more accurate evaluation of team performance when it is measured at multiple levels. It is evident that team performance measures are important throughout many industries, and since not all teams are created equally, it is important to modify the measurement based on the specific team.

Simply, the main purpose of teamwork is to apply an effective method in order to improve the occupational performance of employees and their personal skills and talents that serve the requirements of the job hence, strong leadership and an environment of trust among team members come across as significant factors which can help increase the level of employee performance [9].

\section{E. Theoretical Framework}

Here is the definition of the Freedom what is freedom? the meaning of "freedom is the ability to you do what you want without any rejection, In his history of freedom in Western culture, Orlando opens by stating, "Freedom, like love and beauty, is one of those values better experienced than defined", many factors included for students for their freedom include sex age family income and course they have took. Some of the university students may become stress to them. The stress caused by the living endearment because some students prefer mix gender while some not feel freedom while mix with different gender on same housing area or block. They feel 
unable to do any activity while they mix with housing area or block with different gender. A freedom in choosing accommodation for students there are students who choose off campus accommodation to on campus due to lack of privacy sharing room or place with new students and some decide off campus accommodation for the price which is reasonable or cheaper, new housing and new accommodation with good facilities plus near to university [16]. Stating that compulsory all students must follow the rules and regulation that come from campus and any decision at university campuses "tended to work unilaterally and usually without question, and housing for these students tended to work within the same power structure with colleges instilling restriction rather than freedom and residence with appointed bounds [14].

\section{F. Conceptual Model}

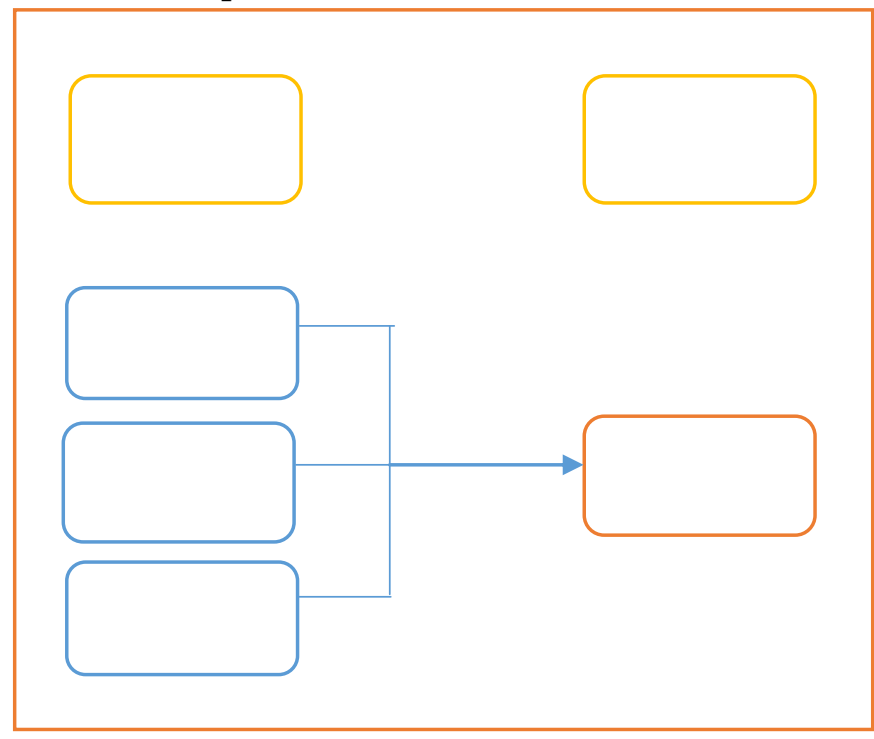

Fig. 1. Theoretical Framework.

H1: There is a relationship between Team Cohesiveness and Employee Performance. Cohesiveness has been constructed based on the bonds of interpersonal attraction, spirit, or sense of belongingness. Studies show the higher cohesiveness the higher employee productivity and tend to defend the norm of the group, participate readily [34].

H2: There is a relationship between Teamwork Quality and Employee Performance. Teamwork is an important element for improving the performance of an organization [13]. Therefore, it is important to develop teamwork spirit amongst the employees [18].

H3: There is a relationship between Team Performance and Employee Performance. Therefore, relying solely on core performance in uncertain and interdependent environments is not sufficient; employees working in these environments also need to be proactive. Proactive performance involves the individual taking action to respond to anticipated change and developing better ways to accomplish one's task [8].

\section{METHODOLOGY}

The empirical study was carried out in a Malaysia university, faculty of business management and the students enrolled in the same course and years but different classes for a few subjects, which favours difficulty in the response but all of us were working in team [6]. As we consistent with the research background and purpose, this study proposed the conceptual framework to examine the linear relationship between the major variables [36] of teamwork including teamwork quality, team cohesiveness, teamwork performance and dependent variables; employee performance. This contains information relating to the purpose of this study, is included the research design, population and sample, measurement and questionnaires and data collection.

\section{A. Research Design}

The forbidding problem that follows the task of defining the research problem is the preparation of the design of the research project, popularly known as the research design. Decisions regarding what, where, when, how much, by what means concerning an inquiry or a research study constitute a research design. A research design is the arrangement of conditions for collection and analysis of data in a manner that aims to combine relevance to the research purpose with economy in procedure [12].

\section{B. Population}

According to [24] states that population can be defined as all people or items that one wishes to understand while sampling is the process of selecting segment of the population for investigation. It is a process of selecting a sample of units from a data set in order to measure the characteristics, beliefs and attitudes of the people. This type of selection is also beneficial to reduce the work burden and cost that would have been involved in studying the whole target population

Therefore, target population is the collection of elements or objects that possess the information sought by the researcher and about which inference are to be made. The target population must be defined in terms of elements, sampling unit, extent $\&$ time.

In the present research, the target population for the survey is employees in a University. The population was composed for the academician and non-academician employees.

\section{Sampling}

The research followed the sampling approach suggested by [29] and also based on the sample size determination by, if there are 100 people of population size, we need at least 80 respondents to answer the survey. A sample size of 100 respondents will be prepare from the population of academician and non-academician members in University. In order to collect primary data, the instruments used are questionnaire will distribute to the employees in the University.

Therefore, the survey will randomly contribute among the 80 employees as respondents in the academician and non-academician in University based on their ability and willingness to answer the questionnaire.

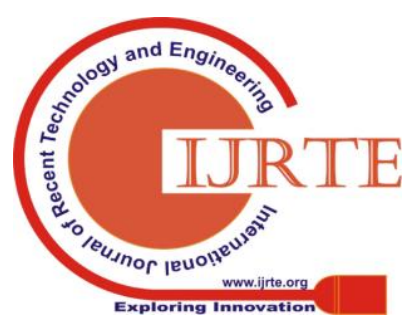




\section{Measurement and Questionnaire}

A questionnaire as a self-report instrument used for gathering information about variables of interest to an investigation. Meanwhile. Therefore, stated that it is intended to measure teamwork skills and focuses on the skills a person should have to be effective in a team. However, a review of the literature in measurement of tram and teamwork showed similarities across industries. Various elements of team were measured, such as team functioning (team type, communication, cohesion and group dynamics), team outcomes (cost, quality, and models), team training (teaching teams and work skills assessment) and team characteristics (innovation and general styles of team behaviour) [15].

Questionnaires are often used to collect information of data from large groups of people. This research purpose, there will be 80 questionnaire will be given to random employees for survey. The questionnaires design used are formal standardized questionnaire where the data collected is to be analyzed statistically based on few characteristics. Besides that, the format used are closed ended format where the questions have multiple options as answers and allow respondents to select a single option from amongst them.

Therefore, the questionnaires were delivered in person. Questionnaires were distributed in after initial communication with the respondents to seek consent. The respondents were given one day to answer the questionnaires after which the questionnaires were collected for analysis.

\section{E. Data Collection}

For the purpose of this research, and in order to achieve the objectives will be collected and will be used only primary data. The primary data will be contributed through questionnaires and surveys towards the target population and respondents.

As for primary data, it may be possible to use the interview approach, also, where the teacher has a preference (some consider a chat to be nicer than a piece of paper) as this will engage them in the process and ensure a personalized feel to the research. This study depends on the primary data because it helps to investigate about what is happening on the ground and also to suggest helpful findings and recommendations [27].

The data used in this research is questionnaires. In fact, thirty-three percent of the subjects were male and seventy percent female, with an average age of $30-50$ years old and an average of 70 percent ( $5-10$ years) of work experience. A total 80 respondents from 100 academician and non-academician from University laboratories participated in this research.

The use of questionnaires is to allow for feedback from a large number of Students, where it is impractical to collect feedback using other more resource intensive methods. Next, to allow each student the opportunity to provide anonymous feedback on their experience. They also help to identify patterns and trends that merit further exploration using qualitative methods.

For the unstructured questionnaires, allow for richer feedback that may provide insight into explanations for what is happening and participants' opinions, attitudes, feelings, perceptions etc. They also allow for issues to emerge that are not necessarily foreseen by the evaluator. The questionnaires are one of the most widely used research methods in the social sciences. Questionnaires comprise a number of questions that participants are required to answer and are therefore usually a self-report research method [32].

\section{CONCLUSION}

The research study revealed that teamwork, cohesiveness, quality and performance have significant to positive impact towards the department of University. Teamwork was found the most significant independent variable having the most significant impact on performance, followed by the others criteria among the team members or colleagues in the place. There is no research taken in Malaysian Universities on the teamwork among the academician and non-academician [17].

The teamwork, team cohesiveness are very important to the management. They are must work together, help each other to get more quality in work. Simply, the main purpose of teamwork is to apply an effective method in order to improve the occupational performance of employees and their personal skills [9].

The teamwork in Malaysia are not free from customer satisfaction issue. In order to meet customer demand and satisfaction, the entire team collaboration including employment skills must be achieved as well. The University has a huge amount of students and staff. An employee performance may affected by numerous factors at workplace and will impact the organization either in a positive or negative way. In order to keep the rating high and maintain the good performance of University, an employee's performance plays an important role to achieving the goals for university. As for our research taken there is also a good impact among all the teamwork in university after the survey.

\section{REFERENCES}

[1] Annalena Welp, A. J. 2017. The Importance of reflecting on practice: How personal professional development activities affect perceived teamwork and performance.

[2] Bacon, N., and Blyton, P. 2006. The Impact of Teamwork on Skills: Employee Perceptions of Who Gains and Who Loses. Human Resource Management Journal. 13, 3 - 29.

[3] Baiden, B., and Price, A. 2011. The Effect of Integration on Project Delivery Team Effectiveness. International Journal of Project Management, 29(2), 29 - 136.

[4] Belbin, R. M. 1981. Management Teams. Why They Succeed or Fail London: Butterworth-Heinem

[5] Boakye, E. O. 2015. The Impact of Teamwork on Employee Performance.

[6] Bravo G. R., Catalan G. S., and Pina P. J. M. 2017. Analysing Teamwork in Higher Education: An Empirical Study on The Antecendent and Consequences of Team Cohesiveness. XXIX Congreso De Marketing Aemark.

[7] Dotun, A., and Dennis, K. 2001. An evaluation of factors influencing teamwork and customer focus. International Journal of Managing Service Quality. 11(1), 49-56.

[8] Griffin, M. A. 2007. A new model of work role performance: Positive behavior in uncertain and interdependent contexts. Academy of Management Journal.

[9] Hisam, S. S. 2018. The Impact of Teamwork on Work Performance of Employees. 
[10] Karma, S. T. 2004. Employee Performance Management Method and System.

[11] Koslowsky, S. S. 2006. Leadership Team Cohesiveness and Team Performance. International Journal of Manpower.

[12] Kothari, C. R. 2004. Research Methodology: Methods and Technique. New Age International ( $P$ ) Ltd. New Delhi.

[13] Mahmood, M. Z. 2012. The Relationship between Group Cohesiveness and Performance: An Empirical Study of Cooperatives Movement in Malaysia. International Journal of Cooperative Studies.

[14] Marks, M., Mathieu, and Zaccaro. 2001. A Temporary Based Framework and Taxonomy of Team Processes.

[15] Marshall, L. 2003. The relationship between efficacy, teamwork skills, effort and patient satisfaction. Unpublished Doctoral Dissertation, University of Southern California, Los Angeles.

[16] Matthew, S. P., Matthew, I. B., Goswami, A., and Christiansen, N. D. 2016. Effects of Team Personality Composition on Member Performance. Group and Organization Management. 43.

[17] MYTO, 2018. 210 Retrieved http://library.utm.my/digital-resources-2/digital-theses/

[18] Layal, S. A. M. 2017. Impact of Teamwork on Employees Performance. International Journal of Education and Social Science.

[19] Oseiboakye. 2014. Employee Perceptions of Corporate Social Responsibility And Organizational Citizenship Behaviours: A Comparative Ghanaian Study.

[20] Pavitt, S. S. 2014. Predicting Top Management Approval and Team Performance in Technology Industry. Moderating Effects of Work Exhaustion.

[21] Pavel, C., John, M. S., and Christopher, J. B. 2003. Assessing teamwork development to improve organizational performance. Measuring Business Excellence. 7(4), 29-36.

[22] Philips, J. L., and Devine, D. J. 2001. Do Smarter Team Do Better: A Meta-Analysis of Cognitive Ability and Team Performance. Small Group Research. 32(5), 507-532.

[23] Pramlal, A. 2004. The Influence of Team Cohesiveness on Team Effectiveness. Univeristy of KwaZulu-Natal.

[24] Rahi, S. 2017. Research Design and Methods: A Systematic Review of Research Paradigms, Sampling Issues and Instruments Development. International Journal of Economics \& Management Sciences.

[25] Rivai, V. 2004. Human Resource Management in Companies 7th edition, Raja Grafindo Pustaka, Jakarta.

[26] Rosh, L., Offermann, R. L., and Van, D. R. 2012. Too Close for Comfort? Distinguishing Between Team Intimacy and Team Cohesion. Human Resource Management Review. 22, 116-127.

[27] Shouvik, S., and Hisam, M. 2018. The Impact of Teamwork on Work Performance of Employees: A Study of Faculty Members in Dhofar University.

[28] Salas, E., Sims, D. E., and Burke, C. S. 2005. Is there a Big Five in Teamwork? Small Group Research. 36(5), 555-599.

[29] Sekaran, U. (2003). Research Methods for Business: A Skill-Building Approach. (Eds) $4^{\text {th }}$. New York, NY: John Wiley \& Sons.

[30] Sihat Sihombing, E. A. 2018. The Effect of Servant Leadership on Rewards, Organizational Culture and Its Implication for Employee Performance. Journal of Law and Management.

[31] Simons, T. L., and Peterson, R. S. 2000. Task conflict and relationship conflict in top management teams: The pivotal role of intragroup trust. Journal of Applied Psychology. 85(1), 102-111.

[32] Stone, A. A., Turkkan, J. S., Bachrach, C. A., Jobe, J. B., Kurtzman, H. S., and Cain, V. S. 2000. The science of self-report: Implications for research and practice. Mahwah, NJ, US: Lawrence Erlbaum Associates Publishers.

[33] Thompson, B. M., Paul, H., and Borges, N. J., Carchedi, L. R., Roman, B. J. B. 2015. Team Cohesiveness, Team Size and Team Performance in Team-Based Learning Teams. 6 Mark $H$ Townsend, 7 Agata $P$ Butler, 8 David B Swanson, 9 Michael P Anderson 10 \& Ruth E Levine Medical Education. 49, 379-385.

[34] Walid, A. S. and Zubair, H. 2016. Impact of Efective Teamwork on Employee Performance. International Journal of Accounting \& Business Management.

[35] Wang, X. H., and Howell, J. M. 2010. Exploring The Dual Level Effects of Transforamtional Leadership on Follower. The Journal of Applied Psyhcology, 95(6), 1134 - 1144.

[36] Wu, M. C., and Chen, Y. H. 2014. A Factor Analysis on Teamwork Performance : An Empirical Study of Inter Instituted Collaboration. Eurasium Journal of Educational Research.

\section{AUTHORS PROFILE}

My name is Zairina Ibrahim, I am from Information Technology and Innovation Centre, Management and Science University, University Drive Seksyen 13, Shah Alam 40100, Malaysia and my area of interest is management and leadership.

My name is Normy Rafida Abdul Rahman, I am associated with Faculty Business Management and Professional Studies, Management and Science University, University Drive Seksyen 13, Shah Alam 40100, Malaysia and my area of interest is management and leadership.

My name is Md Gapar Md Johar, Information Technology and Innovation Centre, Management and Science University, University Drive Seksyen 13, Shah Alam 40100, Malaysia and my area of interest is management and leadership. 